OOPEN ACCESS

International Journal of Advanced Economics

P-ISSN: 2707-2134, E-ISSN: 2707-2142

Volume 3, Issue 2, P.No. 40-57, June 2021

DOI: 10.51594/ijae.v3i2.230

Fair East Publishers

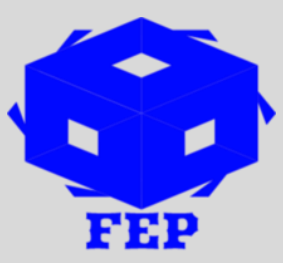

Journal Homepage: www.fepbl.com/index.php/ijae

\title{
THE AGRICULTURAL EXTENSION SERVICES MODE OF OPERATION IN HORTICULTURAL SCHEMES IN WEST COAST REGION IN KOMBO CENTRAL AND NORTH OF THE GAMBIA
}

\author{
Lamin K M ${ }^{1}$, Prof. Idu Ogbe Ode,.$^{2}$, Igbana Ajir ${ }^{2}$ \\ ${ }^{1,}$ Benue State university, Centre for Food Technology and Research, Department of Sociology; Faculty of \\ Social Sciences, Makurdi, Nigeria and University of The Gambia, School of Agriculture and \\ Environmental Sciences, Brikama Campus, Banjul, The Gambia \\ ${ }^{2}$ Benue State University, Faculty of Social Sciences, Department of Sociology; Makurdi, Nigeria
}

*Corresponding Author: Lamin K M

Corresponding Author Email: 1kmfatty@utg.edu.gm

Article Received: 29-04-20 Accepted: 17-05-21

Published: 06-06-21

Licensing Details: The author retains the right to this article. The article is distributed under the terms of the Creative Commons Attribution-Non-Commercial 4.0 License (http://www.creativecommons.org/licences/by-nc/4.0/) which permits non-commercial use, reproduction, and distribution of the work without further permission provided the original work is attributed as specified on the Journal open access page.

\begin{abstract}
The study assesses agricultural extension services mode of operation in horticultural farms for smallholder farmers in Kombo Central and North, West Coast Region of The Gambia. The instruments designed to gather the primary data include; structured interview and focus group discussions (FGD) supported by secondary data using official documents and key informant interview for verification. The target population consisted of 398 respondents, 10 extension officers and three extension agent heads. The data was quantitatively analyzed using percentages, frequency distribution tables, t-test, chi-squared test correlation and factorial analysis. Qualitative data from the in-depth interviews were also analyzed and presented appropriately. It was found that the variables on the influence of extension services (availability of AES, extension visit, farm size, marital status, experience in farming, education, farm group, transportation, post-harvest technology training and distance to market) are significantly associated with the horticultural smallholder farmers post-harvest losses. It means that there is a significant relationship between extension availability and post-harvest handling at $p<0.05$ level of significance. The research comes out with the following recommendations; the need for continued research, development and investment programmes in extension, effective and efficient communication to the farmers, availability of horticultural production, government
\end{abstract}


policy aimed at training and developing farmer capacity in appropriate monitoring systems of extension services, road improvement in the study areas and creating better improvement conditions for the extension agents. The study proves the need to improve the living conditions of services for extension services and availability of extension officers at a regular base with appropriate knowledge and skills.

Keywords: Agricultural Extension Services, mode of Operation in horticultural Schemes, West Coast Region, Kombo Central, North, The Gambia.

\section{INTRODUCTION AND LITERATURE REVIEW}

Smallholder vegetable farmers have been given little attention with regards to appropriate extension and research, and the situation is still similar today. Extension of inappropriate services often results in the lost chance of essential capacity building opportunities. Research therefore, emphasises the important role of capacity building where farmers are taught good farming and handling practices (Martins, Hogg, \& Otero, 2012).

According to Department of Agriculture (DOA, 2013), the Ministry of Agriculture (MOA) in The Gambia is tasked with the responsibility of policy formulation and administration of all agricultural programmes projects and policies including the extension sector. Under it there are four sub-departments, each with distinct roles in the agricultural policy, programme and project implementation process. The four major sub-departments are: Department of Agriculture (DOA), Department of livestock Services (DLS), National Agricultural Research Institute (NARI) and Central Project Coordination Unit (CPCU). The Extension service is an agent of the Government currently monovalent and has been undergoing restructuring for the past few years, aimed at ensuring effective and efficient service delivery. According to Agriculture and Natural Resource Programme (ANRP, 2009), the service is currently relying mainly on agricultural projects for capacity building as well as support to farmer training. The service is presently understaffed at field level with an Extension Worker/farmer ratio of over 1: 2000 or even 1:3500. Nearly $70 \%$ of the highly professional qualified personnel reached retirement in the next seven years, raising the need for an urgent up scaling of the sub-sector's human capacity in order to meet emerging challenges. Most of these extension trainees focused on agronomy practices rather post-harvest technologies. The sector's objectives are focused on development of the small producers for productivity and competitiveness. The extension service will be central to get the necessary messages across to the small holders who may not have had the opportunity to see, let alone adopt new technologies especially in post-harvest losses. Thus, the benefit of post-harvest technology of horticultural farmers will improve their income, surplus to the market for sale and consume available food to the community which will results to poverty reduction. A good agricultural extension services establishment at post-harvest technology can contribute a lot to the food loss reduction, improve farmers' income status, standard of living, increase income and poverty reduction. In light of the above forgoing issues, the study is therefore designed to examine the agricultural extension services and post-harvest losses of horticultural crop produces in Kombo Central and North, West Coast Region of The Gambia.

This research sets out to assess the role of agricultural extension services and post-harvest losses of horticultural crop produce in West Coast Region of The Gambia. In general, food insecurity is linked to high food prices, poverty and low agricultural productivity and much attention has not been focused on extension effect on post-harvest loss aspect (Dávila, 2010; Lewin, 2011; 
Nyangweso, Odhiambo, Odunga, Korir, Kipsat, \& Serem, 2007). In spite of the fact that the Gambian government gave special attention to the agricultural sector and tried to establish and support agricultural research institutes, research stations in the country are too few to cover the whole country. It has also been supported by (GOTG, 2008, report and GOTG, 2010) that improved post-harvest practices are basically tried in few research stations and at farmers' fields near the stations but disseminated to a large area. In some parts, there is also problem an effective agricultural extension services in post-harvest reduction, resulting in low prices of agricultural products as production increases, which is expected under extension-based farming. Yet access to adequate knowledge, improved technologies especially post-harvest practices and other relevant social services remains a critical issue. Besides, there is no research undertaken in the study area on any specific crop or management practices, or on how the extension programme to improve on post-harvest technologies. Furthermore, not much attention has given to the role of agricultural extension services on post-harvest handling. Therefore, this study helps to give an image of agricultural extension going on in Kombo Central and North district of West Coast region of The Gambia.

A wide range of accessibility of agricultural extension services delivery systems have been tried in many developing countries for the farmers, but very little has been achieved in systematically considering a post-harvest practices perspective in the provision of agricultural advisory services. Many farmers' access to agricultural extension services, through a variety of mechanisms, but they have not been scaled for significant impact especially post-harvest technologies. While the need for an efficient and effective services delivery is increasingly recognized, the challenge of how farmers' access agricultural extension services remain some serious challenges. It is against this background that this study seeks to examine the nature and access to agricultural extension services by horticultural farmers on post-harvest losses in Kombo Central and North of West Coast Region of The Gambia.

The objective of the study is to examine agricultural extension services mode of operation and nature of agricultural extension services available to smallholder horticultural farmers in horticultural farms in Kombo Central and North, West Coast Region of The Gambia. In the light of the foregoing, the following specific research questions are outlined to guide the study: What is the mode of operation and nature of agricultural extension services available to smallholder horticultural farmers in Kombo Central and North District of West Coast Region of The Gambia?

\section{Nature of Agricultural Extension Services and Mode of Operation}

Extension is multidisciplinary. It combines educational methodologies, communication and group techniques in promoting agricultural and rural development. It includes technology transfer, facilitation, and advisory services as well as information services and adult education (Rivera and Qamar, 2003). It is dependent for success on other agricultural development processes such as marketing and credit services, not to mention economic policy and physical infrastructure. In short, it is a function that is dependent for success on other factors, including other services and institutions. In many cases its success depends on the ability to shift programme direction and development to stakeholders and programme users. No matter what the name of the system, approach or programme (cooperative extension, advisory services, Special Programme for Food Security, technical assistance or technology transfer), the function remains that of extension: the transfer and exchange of practical information. At the same time, extension is a political and organizational instrument utilized to facilitate development. 
Internationally, extension's institutional systems tend to differ from country to country nonetheless is very vital in farming operations.

\section{Extension Function and Importance}

Extension, in general terms, is a function that can be applied to various areas of society. It operates in the industrial, health and education sectors, as well as agricultural and rural development, (Rivera, 2001). Most ministries of agriculture have an extension unit that deals mainly with crops and mixed agricultural systems, as well as separate technical divisions (livestock, forestry, fisheries) some of which also provide extension services also common in The Gambia. During the 1970s and 80s, efforts were made to unify ministerial agricultural extension operations but with limited success. This same diversity and separation of agricultural extension activities exists in international organizations. In many cases its success depends on the ability to shift programme direction and development to stakeholders and programme users and Gambia is not an exception.

When systematically and effectively provided, extension is known to enhance social and economic development. Technological change and the knowledge system that underpins it, is a critical factor in development (World Bank, 2003). Despite the difficulty of isolating its impact on agricultural productivity and growth from that of other factors, many studies have demonstrated the high economic returns of investments in agricultural dissemination. Investment in agricultural research and extension is thus a crucial input of agricultural growth (Anderson and Feder, 2004). Agricultural extension has been reoriented to meet with the changing situation of liberalisation head on. Farmers in remote areas are being encouraged to grow food crops first to ensure food security. However, such farmers are also encouraged to grow high value crops and crops which do not need high fertilizer applications as cash crop. An improved information and knowledge flow to, from and within the agricultural sector are a key component in improving small-scale agricultural production and linking increased production to remunerative markets, thus leading to improved rural livelihoods, improving quality and yield, food security and national economies. The agricultural sector is the backbone of many economies in Africa. Various studies have revealed that there is a positive relationship between the increased flow of knowledge and information and agricultural development.

However, most African countries have not devoted their efforts to the dissemination of knowledge and information, especially in rural areas, where 70-80 per cent of the African population lives (Adomi et al., 2003). Only a small amount of agricultural information is accessible to rural farmers, despite the large body of knowledge that exists in research institutions, universities, public offices and libraries. This situation is largely attributed to the weak linkages between research, extension, not for profit organizations, libraries and farmers and thus these technologies have neither reached nor been adopted by their intended beneficiaries to improve their farming activities in developing countries including The Gambia. It is widely recognized that increasing agricultural production is, in many parts of the developing world, an important component of a strategy to increase incomes, reduce hunger, post-harvest losses and contribute to the improvement of other measures of well-being. Doing so requires improvements in the productivity of factors of production. Owens, Hoddinott, and Kinsey (2003), showed that agricultural extension represents a mechanism by which information on new technologies, better farming practices, and better management can be transmitted to farmers. It is not surprising, therefore, that considerable amounts of funds, running into the hundreds of millions of dollars, are disbursed annually in support of agricultural extension and that the impact of agricultural extension has received considerable attention. 


\section{Extension Typologies /Approaches}

Generally, there are many models and types of extension activities, and several authors have given typologies of extension for illustrative review. This paper views extension as generally (but not always) falling into 3 broad categories: diffusion or government-driven; participatory or demand-driven; and private or supply-driven, with the different systems or models falling under these three. According to Gêmo, Eicher, and Teclemariam (2005), many extension systems in Sub Saharan Africa (SSA) today are mixtures of these broad categories: Public, Commodity, Training and visit (T\&V), Non-Governmental Organisation (NGO), Private sector and Farmer field schools (FFS). Several approaches have been tested and adopted by countries in Africa to improve the technology dissemination process. Many extensions approach currently in use in Gambia and other SSA are combinations of these broad categorizations. In The Gambia approaches of agricultural extension range from the top-down commodity-based approaches of the pre-and post-independence to more participatory approaches. Specifically, the approaches that are still being used include the World Bank's Training and Visit (T\&V), commodity, and participatory approaches and most recently farmer field schools (FFSs) in addition to innovative ICT based approaches which provides advice to farmers on-line and other approaches such as the promotion of mobile phones and community radio stations. However, majority of Gambian farmers are not literate to adopt the innovative based approach but could come up with increase number of farmers' children being educated. These approaches are discussed below.

\section{a. Training and Visit $(T \& V)$}

$\mathrm{T} \& \mathrm{~V}$ is one of the earlier approaches that focused on transfer of technology using a top-down, one-size-fits-all approach. This approach was introduced after the department of agricultural extension services (DAES) had been organized under the unified extension systems (UES) concept. Existing extension organizations were merged into a single national system. This approach was designed on the assumption that farmers lack technical knowledge for increasing productivity, hence the solution was therefore to provide them with modern technical knowledge. If this approach is effectively and efficiently applied with proper monitoring and application of appropriate practices, it may produce a desired result in post-harvest handling. The approach is based on a set of managerial and organizational principles that are of broad applicability and which, when applied together, constitute an extremely powerful managerial tool (Yudelman, 1984). The approach differs from the general extension by its emphasis on frequent in-service training for staff, regular visit to farmer' farms, promotion of extension/research linkage and improved extension management (Benor et al., 1984). In the process of service delivery, subject matter specialists (SMS) gave training to frontline extension agents on new but relatively simple technical issues, the extension agents then proceed to train farmers and/or farmer groups on the new technologies. This approach uses extension methods including group discussions, seminars and in-service training courses for extension staff and farmers, on-farm demonstrations and farmer field days (en-ext). Specific tools were: contact to a determined number of farmers ${ }^{\text {ee }}$ groups, handouts and technical fact sheets. T\&V had been designed as a cost-efficient extension system. The delivery of messages was considered economic; as large numbers of farmers could be reached fortnightly. However, due to the relatively high financial outlay required, the $\mathrm{T} \& \mathrm{~V}$ approach could not be sustained at the end of World Bank funding. The approach came under attack in the 1980s due to the cost of financing coupled with criticisms of irrelevance, inefficiency, ineffectiveness, and lack of equity (Rivera, 2001). It was also criticized due to the passive role allocated to farmers, as well 
as the failure to factor in the diversity of the socio-economic and institutional environments facing farmers and ultimately in generating behaviour change (Birner, Davis, Pender, Nkonya, Anandajayasekeram, Ekboir, \& Bollen, 2006).

\section{b. Participatory Approaches}

The passive role of farmers in the $\mathrm{T} \& \mathrm{~V}$ approach necessitated the promotion of participatory approaches where the need for empowerment of the farmer is paramount. In this approach the role of the extension agent is to facilitate an in-depth situation analysis by the farmers themselves at the onset of their working relation. Once farmers have become aware of the causes of their problems and have identified the most pressing ones, the extension agent provides technical knowledge and technologies, which may be useful to address the problems identified. For this approach to work well, extension agents need not only agricultural expertise, but also good analytical, pedagogical, and facilitating skills (en-ext). What makes this approach participatory is that farmers are the principal decision-makers in defining goals, planning, implementing, and evaluating development activities. This helps in strengthening farmers' problem-solving abilities from the start. In relation to community development, the existence of a local government and a decentralized administration is a precondition. If the local government is not dominated by elites, then the accountability, effectiveness, and efficiency of local services can be substantially improved. Reality still looks different, but too much political pressure from donors could mean that solutions are imposed, running the risk of being rejected, and subsequently degenerating into a mechanistic application of the instruments. Moreover, participatory approaches depend strongly on a conducible political and administrative environment. For finding appropriate technological answers to farmer questions, researchers must take into account local constraints, risks, and cultural preferences. Therefore, it is best to involve farmers at all stages of the research process, from the definition of research issues, through the planning phase, implementation, and evaluation of research results.

\section{c. Farmer Field Schools (FSS)}

Farmer Field School is a participatory method of learning, technology development, and dissemination based on adult-learning principles such as experiential learning and introduced in Sub-Saharan African (SSA) in the mid-1990s. They are being used in at least 27 SSA countries (Braun, Jiggins, Roling, van den Berg, and Snijders, 2005). FFS originated from Asia, where it was developed to promote integrated pest management (IPM) programs. However, in Gambia FFS are being used for a variety of activities, including food security, animal husbandry, and soil and water conservation. Farmers meet regularly for the duration of an entire cropping season. They learn by observing what is happening on the field, by discussing in groups what they have observed, and by hands-on management of the field from pre-planting to harvest. Through group interactions, attendees sharpen their decision-making abilities and are empowered by learning leadership, communication and management skills. Some of the participating farmers are selected to receive additional training so as to be qualified as farmertrainers, who then take up training responsibilities (for some fee, possibly paid by their community) with official backup support such as training materials. This approach aims to increase the technical competence of farmers concerning a single crop (rice, cotton, beans and other horticultural crops) or livestock, and to strengthen the social competence and confidence of farmers.

\section{d. The Commodity Approach}

This approach is generally organized through parastatal organisations or private sector firms. The basic characteristic of this approach is that the production system is vertically integrated 
from input supply to the technology adoption and marketing of the produce. Farmers (out growers) produce a certain quantity and quality of a crop, animal species or animal product, and sell it to the company which is partnering them. In return, the company (sometimes also called sponsor or purchaser) provides inputs, credit, as well as extension, quality management (standards) and marketing services. It usually focuses on a single one cash crop (ext approach). These companies are often private multinational companies, processing plants or government agencies. However, small companies, farmer co-operatives, or individual entrepreneurs can be running out grower schemes. Under favourable conditions, this approach may provide small farmers with an array of agricultural services to which they otherwise would have no access. This type of arrangement is becoming increasingly relevant as public service delivery to the agricultural sector declines and the involvement of the private sector in providing agricultural services increases.

\section{Agricultural Extension in The Gambia}

The agricultural extension programme which aims to increase the knowledge and skills of farmers through the dissemination of improved agricultural technologies focuses mainly on crop improvement, Human Resource Development and a collaborative programme with other government departments and Non-governmental organisation. In response to the Vision 2020 agricultural objectives and the fact that the crop sub-sector plays a pivotal role in the economic development of The Gambia, extension efforts is focused towards more impact-oriented strategies in attaining food security and thus alleviating poverty. The Extension agenda continues to focus on the use of improved varieties, soil fertility maintenance/conservation, effective water management techniques, processing and preservation technologies. This and other Department related achievements in food and cash crops production are discussed in this document.

The Extension service is an agent of the Government currently monovalent and has been undergoing restructuring for the past few years, aimed at ensuring effective/efficient service delivery. According to (ANRP, 2009), the service is currently relying mainly on agricultural projects for capacity building as well as support to farmer training. The service is presently understaffed at field level with an Extension Worker/farmer ratio of over 1: 2000. Nearly 70\% of the highly professional qualified personnel will reach retirement within the next five years, raising the need for an urgent up scaling of the sub-sector's human capacity in order to meet emerging challenges. The sector's objectives are focused on development of the small producers for productivity and competitively. The extension service will be central to get the necessary messages across to the small holders who may not have had the opportunity to see, let alone adopted new technologies to be adopted.

\section{Agricultural Extension Structure in The Gambia}

According to (DOA, 2013), the Ministry of Agriculture (MOA) in The Gambia is tasked with the responsibility of policy formulation and administration of all agricultural programmes projects and policies. Under it there are four sub-departments, each with distinct roles in the agricultural policy, programme and project implementation process. The four major subdepartments are: Department of Agriculture (DOA), Department of livestock Services (DLS), National Agricultural Research Institute (NARI) and Central Project Coordination Unit (CPCU).

\section{Department of Agriculture}

The Department of agriculture is mandated by the Ministry of Agriculture to implement agricultural extension activities. However, extension activities are carried out in close 
cooperation and collaboration with the Departments of Livestock, National Agricultural Research Institute, projects and Non-Governmental Organizations e.g., FAO. The Department consists of eight technical service units and six regional agricultural directorates spread in seven Regional Administrative divisions of The Gambia. At regional level, The Regional Director works with senior and junior agricultural officers specializing in various fields such as agronomy, planning, agricultural economists, horticulture etc. The directorate is responsible for organizing, coordination and implementing daily extension services to rural communities. There are sub-stations in each district called district extension centres (DECs). These centres are headed by the district extension supervisors (DES) who supervises all the village extension workers within the district. The DEC serves not only as bases for the village extension workers but primarily functions as training and demonstration centres for farmers (DOA, 2013). In The Gambia, extension service is generally based on the Training and Visit system where farmers are trained and later visited by the extension worker to monitor or reinforce the practice and adoption of the technology. Extension service is mainly carried out in three methods which are used to disseminate agricultural innovations and recommended practices to farmers (DOA, 2013). These are the following methods: (a) The individual Method: Famer is met individually by the village extension agent who is posted to cover between 5-10 villages and extension service rendered; (b) Group Method: This method is usually done during training of famers before or during the cropping season where the extension agents stationed in villages organize famers in sizeable groups and render the necessary extension service to them, and (c) Mass Communication: This involves the use of radio talks, television programmes, film shows and other print media such as newspapers, leaflets, pamphlets, magazines etc. The Communication, Education and Extension Services carry out this function with other staff of the Department of Agriculture. Usually, a large number of farmers are invited and trained mostly at the two main extension training centres at Chamen in North Bank Region or Genoi in the Lower River Region. The technical service units on the other hand have their headquarters in the West Coast Region and Kanifing Municipality but uses extension workers in conducting their respective activities.

I. Horticultural Technical Services (HTS): This is responsible for implementation of horticultural related programmes. It provides technical expertise's to farmers engaging in horticulture across the country. It is headed by a deputy director and assisted by senior and junior staff specialists in horticulture.

II. Agribusiness Services (ABS): Formerly called Cooperative Unit, its core mandate is to organize and provide statutory registration to cooperatives and farmer organizations. This function as: Linking and facilitating marketing opportunities; provide training on microfinance and organizational management for farmer groups, and works with input suppliers for the procurement and distribution of agricultural inputs to farmers.

III. Soil and Water Management Services (SWMS): The soil and water management perform the following: Land development and land reclamation; Provides technical expertise in the construction of cause ways, spill ways and bridges in low land area in collaboration with agricultural projects, technical support in soil fertility maintenance and training to farmers.

IV. Agriculture Engineering Services (AES): This unit is the one that is responsible for all the engineering provision for the ministry as: Provide training on the use of machinery e.g., tractor, power tillers, shine hoes; Advices the Ministry on the procurement of Agricultural machinery, and Innovation and maintenance of farm machinery and equipment. 
V. Communication Education and Extension Services (CEES): This is the media organ of the Department of agriculture: It provides video and newspaper coverage for agricultural training programmes; produces a weekly bulletin of farming activities called "senelaal" (a Mandinka word meaning the farmers and informs the public through the television, newspaper and radios of the major agricultural activities as they take place across the country.

VI. Planning Services (PS): This unit assists in the formulation of agricultural policies, programmes, and projects in collaboration with government and development partners: Prepares annual budget for the Ministry of Agriculture and handles all data and information from extension; Conducts pre-harvest and post-harvest assessment and prepare the annual National Agricultural Sample Survey Report (NASS) and Planning and reviewing of agricultural strategies, programmes and policies.

VII. Plant Protection Services (PPS): Provides technical support to pest and disease management/control; Recommends to government purchase of agrochemicals (herbicides, pesticide, drugs) and Conducts inspections for the imported and usage of agrochemicals.

VII. Food Technology Services (FTS): This is responsible for providing training in post-harvest losses, food storage, food processing and preservation. They also train farmers on food product development for food vendors.

\section{Department of Livestock Services (DLS)}

This unit is responsible for organizing and coordinating all livestock related activities like vaccination, diseases surveillance and prevention, livestock production and marketing, and livestock breeding. Recently they have been separated as a section of its own from DOA and have its own extension officers in various regions

\section{The Central Project Coordination Unit (CPCU)}

This was set up by an Act of parliament to coordinate and monitor all projects under the Ministry of Agriculture. Their role is to monitor projects activities to ensure effective and efficient implementation.

\section{National Agricultural Research Institute (NARI)}

The National Agricultural Research Institute was established in 1993, by an act of parliament of the Republic of The Gambia. It is responsible for planning organizing and coordinating adaptive research throughout the country. The Institute is also headed by a Director General who is assisted by the director of research and other senior officers. NARI work with DOA extension staff at field level during the research process. Furthermore, this unit is an autonomous body that functions separately from the ministry yet still remain under the ministry of agriculture. NARI comprises three main divisions: Research which is the scientific wing of the institute, Finance \& Administration, and Technical Support. NARI maintains two main research stations, one at Sapu in Central River Region-South (CRRS) and the other in the West Coast Region at Yundum. In addition to these main stations, NARI operates in several satellite research stations countrywide: At the institutes' headquarters, Brikama, three laboratories for pest management, soil analysis, and food quality analysis respectively. It collaborates with Department of Agriculture, FAO, Department of Livestock and several international research institutes such as International Agricultural Research Centres (IARCs) International Institute for Tropical Agriculture (IITA) in Ibadan, Nigeria.

The extension messages can be very broad and may have to depend on the area of research findings and recommendations. In The Gambia, each of the unit has their own extension agents that are deployed in the field but works in collaboration with the other units and the ministry as a whole. Some of the extension messages include but not limited to the following: Weed control 
methods, Techniques of soil fertility maintenance, Good agronomic practices (planting, spacing, weeding, fertilizer application, erosion control, harvesting, handling and storage); integrated pest management (IPM), Post-Harvest Management Techniques, Organizational Management, Machinery operation and maintenance, Record keeping and Farm management.

\section{RESEARCH METHODS}

This chapter presents the procedures that were used in conducting the study. It is organized into the following themes or sub-headings: research design and description, research setting, populations of the study, sampling techniques, method of data collection, validity and reliability, techniques of data analysis and problems or limitation encountered in the course of study. The study used survey research design adopting the cross-sectional method. According to Orodho (2004), the purpose of survey is to produce quantitative descriptions of some aspects of the study population. Survey analysis is primarily concerned with relationships between variables. This study seeks the contributions of the agricultural extension services and postharvest loss of horticultural farmers in WCR. Survey research is a quantitative method, requiring standardized information from and/or about the subjects being studied. The subjects studied individuals in a particular group, organization or community. For this case the subject of study is the horticultural farmers and agricultural extension services in WCR including some key informants for qualitative data.

The study was carried out in West Coast Region (WCR) of The Gambia focusing on Horticultural farmers (fruits and vegetable Farmers), agricultural extension workers and extension supervisors in the Region. The Republic of the Gambia is located on the Atlantic Coast of Africa, between latitudes $13^{\circ} \mathrm{N}$ and $14^{\circ} \mathrm{N}$ and Longitude $14^{\circ} \mathrm{W}$ and $17^{\circ} \mathrm{W}$, occupying a total area of $11,420 \mathrm{sq} \mathrm{km}$. The Gambia consists of two narrow strips of land 6 to $26 \mathrm{~km}$ wide extending $320 \mathrm{~km}$ east along the banks of The River Gambia. The Republic of Senegal is The Gambia's only neighbour: Occupying an area 20 times the size of the Gambia, Senegal surrounds The Gambia on north, east and south. West Coast Region is located at the western part of The Gambia bordering the Atlantic Ocean and Kanifing Municipal Council North, Lower River Region East, River Gambia and Cassamance (Senegal) figure 2. According to National Agricultural Sample Survey (2013), there are 82 vegetable gardens and a total of 13,800 members both male and female. In Kombo Central and North, there are 23 vegetable gardens comprising of 2,836 members 2,756 females and 70 males. The target population in the study comprise of all the sampled horticultural farmers involved in fruits and vegetable farming in Kombo Central and North, Agriculture Extension Agents and heads of district agricultural officers in the study area. Kombo Central and North have a total household population of 61,241 in which sample size is drawn from, and there are 14 extension agents and three agricultural extension service heads/supervisors (National Agricultural Sample Survey, 2013).

\section{Sample Size Determination}

The six sub-locations covered in the study are found in the two districts (Kombo Central and North) in WCR where there are many horticultural schemes. In establishing a sample size, a multistage sampling procedure was used. The two locations and the six sub-locations there in were purposively selected in the first with the aid of the village extension officers. A sampling frame of 61,241 population of horticultural farmers was compiled with the assistance of the regional horticultural extension officers from the ministry of agriculture (MoA) based in WCR and several village elders as from the National Agricultural Surveys (NAS, 2013). In the next stage, a sample size of 398 respondents was randomly drawn from the sampling frame by 
adopting Taro Yamane (Yamane, 1973) formula with 95\% confidence level, for sample size formula for categorical data which incorporated a margin of error of 5 percent and obtained a sample size of 398respondents.

\section{Sampling Technique/Procedure}

The study used cluster and purposive sampling method in order to form the sample size from the population as follows: In cluster Sampling: - The area was clustered into nine districts in West Coast Region and in consultation with the Ministry of Agriculture extension staff, two locations/districts were purposively sampled. In consultation with extension staff, two horticultural farms were purposively sampled from cluster A (Kombo Central) and four horticultural farms from cluster B (Kombo North) based on the establishment and size of the scheme giving a total of six horticultural farms/schemes. We then use simple percentage calculation to calculate the representative from each horticultural scheme and then used simple random sampling to select individual respondents giving a total of 398 horticultural farmers from the identified horticultural farms. The study selected 10 extension officers and two head or supervisors in the district using purposive sampling method as key informant.

\section{Data Collection Method}

Primary data on farmer demographics, socio-economic characteristics, the production, postharvest handling, extension services activities operation, and access to information on postharvest practices were directly obtained through an interview-based survey. This was done by trained enumerators supervised by the researcher using a detailed and well-structured of interview question designed in line with the objectives of the study. A focus group discussion and key informant interviews preceded the main survey to provide in-depth information on horticultural crop produce loss. These two exercises also provided ideas for developing and fine-tuning the survey tool. The study used multiple sources of information, both primary and secondary (referred as triangulation) to ensure construct validity and reliability of the data collected. A structured questionnaire was developed for the horticultural farmers while a Semi structured questionnaire developed for the extension officers and the district extension supervisors. The interview schedule was used to seek information on general characteristics of respondents, production information post-harvest technologies and constraints faced by the horticultural farmers. Primary data is information gathered directly from field (Kombo \& Tromp, 2006).

\section{Techniques of Data Analysis}

The data generated/collected from 398 horticultural farmers was cleaned before analysis to ensure internal validity. Descriptive and econometric tools were used to assess the extent and influences of post-harvest horticultural crop loss experienced through various factors by farmers as well as to assess horticultural farmers, socio-economic and farm-specific factors likely to influence farmers for improvement on the post-harvest loss reduction. Data on sociodemographic attributes of respondents, utilisation of horticultural produce, production issues, post-harvest technologies, agricultural extension services, were analysed quantitatively using statistics such as percentages, frequency distribution tables, t-test, chi-squared test correlations.

\section{RESULTS AND DISCUSSIONS}

\section{Nature of Agricultural Extension Mode of Operation at the Horticultural Schemes}

Data collected on the agricultural extension services mode of operation available to smallholder horticultural farmers in West Coast Region in Kombo Central and North of The Gambia. The factors considered were: awareness of extension services, times/number of 
agriculture extension visits, farming methods, training type, number of training post-harvest technologies and advice areas given.

\section{Availability of Agricultural Extension Services and horticultural schemes}

The availability of the extension services to the horticultural farms plays a significant role in farmers adoption and efficient delivery and the data for this is presented in table 1 below for details. Table 5 above discussed the horticultural schemes and their availability of agricultural extension. Accordingly, majority (280: 70\%) of the schemes are aware of the extension services and their activities in the area while (122: 30\%) of them said they are not aware, however, FGD discussion supported the availability of extension service in all the schemes. Even though majority has known the existence of the extension activities, it has not reflected on their involvement in technology adoption especially post-harvest technologies as also stated that very few had participated in such activities. Availability of extension service to farmers plays an important role in terms of creating knowledge and skill in using improved agricultural inputs. The government is the only agency which provides extension service in the study area. During the study time, there were no development agents assigned by government to provide extension services to the farmers in the area. Frequency of extension service was measured and the results are indicated in table 1.

Table 1

Horticultural Farm and Availability of Agricultural Extension Services

\begin{tabular}{l|rrr}
\hline & \multicolumn{4}{|c}{ Availability of Agricultural Extension Services } \\
Horticultural Farm/Organisation & Yes & No & Total \\
\hline Dasilami & 72 & 67 & 139 \\
Marakessa Vegetable Garden & 34 & 49 & 83 \\
Lamin Women Garden & 59 & 1 & 60 \\
Banjulunding Vegetable Garden & 38 & 3 & 41 \\
Young Farmer's Club & 38 & 0 & 38 \\
Sukuta Women's Garden & 37 & 0 & 37 \\
\hline Total & 278 & 120 & 398 \\
\hline
\end{tabular}

(Source: Field survey 2018)

\section{Frequency of Extension Services Visit to Horticultural Farms}

The data on extension visits to the farms is presented in table 2 below that also has an influence on post-harvest loss of crop produce. Table 2 revealed that $94 \%$ (130) of horticultural farmers affirmed that extension agents visited Dasilami farm monthly in the scheme. Also, 96\% (80) of Marakessa farmers, 92\% (55) of Lamin, 66\% (25) of Busumbala had monthly extension visit respectively. However, both Banjulunding and Sukuta farmers (95\% (39) and (35)) affirmed that extension agents visited them weekly. The implication is that both Banjulunding and Sukuta are right on the highway and easy access to the be available which could be a cause for weekly visit. Those who had been having regular visits were due to easy proximity, access and good road conditions to the schemes by the extension agents who were expected to guide and disseminate information to farmers. Some of the farmers, especially those from Banjulunding and Lamin Camp said they learnt of some of the recommended practices from programmes organised by the Taiwanese Technical mission, other Project Demonstration Farm and neighbouring farmers with the skills, while some learnt the improved practices of farming particularly through local processing units. 
Table 2.

Frequency of Extension Services Visit to Horticultural Farms

\begin{tabular}{l|rrrrrrrrrr}
\hline & \multicolumn{1}{c}{ Times of Extension Visits } \\
Horticultural Farms & Daily & Weekly & Monthly & Yearly & \multicolumn{1}{c}{ I don't Know } \\
& F & $\%$ & F & $\%$ & F & $\%$ & F & $\%$ & F & $\%$ \\
\hline Dasilami & 0 & 0 & 0 & 0 & 130 & 94 & 0 & 0 & 9 & 6 \\
Marakessa & 0 & 0 & 0 & 0 & 80 & 96 & 0 & 0 & 3 & 4 \\
Lamin & 0 & 0 & 0 & 0 & 55 & 92 & 0 & 0 & 5 & 8 \\
Banjulunding & 0 & 0 & 39 & 95 & 0 & 0 & 0 & 0 & 2 & 5 \\
Busumballa & 0 & 0 & 35 & 95 & 0 & 0 & 0 & 0 & 13 & 34 \\
Sukuta & 0 & 0 & 0 & 0 & 25 & 66 & 0 & 0 & 2 & 5 \\
\hline \multicolumn{1}{c}{ Source: Field survey, 2018) }
\end{tabular}

\section{Horticultural Farm and Farming Method}

The data in table 3 below describe the horticultural farm and the different form of farming methods adoption. In table 4 above, comparing the different farms on the farming methods used at the various schemes mostly had been using improved method a frequency of 217 (55\%). At each individual scheme, majority (e.g., all 41:100\%) in Banjulunding were trained on improved method although, in some of the schemes the number of farmers using improved method is low (e.g., 9 out 41 in Lamin Women garden). However, this has not reflected on the post-harvest technology training rather it was on the other agronomy practices. The probability is that the extension operation method for the farmers adapting the improved method is not efficiently and effectively done or were not on post-harvest handling which caused it not been reflected on post-harvest technologies as part of the training needs.

Table 3

\begin{tabular}{|c|c|c|c|c|c|}
\hline \multirow[b]{2}{*}{ Horticultural Farm/Organisation } & \multicolumn{5}{|c|}{ Farming Method } \\
\hline & Conventional & Percent 1 & rovedf & rcent & Total \\
\hline Dasilami & 66 & 47 & 73 & 53 & 139 \\
\hline Marakessa Vegetable Garden & 49 & 59 & 34 & 41 & 83 \\
\hline Lamin Women Garden & 51 & 85 & 9 & 15 & 60 \\
\hline Banjulunding Vegetable Garden & 0 & 0 & 41 & 100 & 41 \\
\hline Young Farmer's Club & 5 & 13 & 33 & 87 & 38 \\
\hline Sukuta Women's Garden & 10 & 27 & 27 & 73 & 37 \\
\hline Total & 181 & 45 & 217 & 55 & 398 \\
\hline
\end{tabular}

\section{Horticultural Farm and Training Type}

From the results, it was revealed in table 8 below, the training type given at the various schemes in terms of post-harvest training were harvesting, handling, packaging, storage and other (agronomy practices). Of all the trainings done as shown in table 4 above, agronomy practices were the highest $(84.92 \%)$ while on post-harvest training combined just formed about $15.08 \%$ indicating that less post-harvest technology is applied in all the schemes with high concentration 
on production. The results show a general lack in sufficient post-harvest handling practices to have a significant impact on post-harvest loss reduction. This also has thus contributed to high loss of produce both before and after sales and probable indication of most or all the extension agents are not or have less skills to train the farmers on post-harvest technology or even their operation is very minimal in schemes. If ever training is to have an impact on post-harvest handling practices, there is however a need for this training to be repeated more often. Key informant interviews revealed that some of the farmers had received fruit and vegetable training more than a year before the survey was conducted. This is also supported from the focus group discussions in all the schemes and the key informant discussions where it was stated that though there are times when some workshops and farm field schools were conducted for farmers on food processing but few farmers have the opportunity to attend which is not also enough to train them to train others at community level. It was highlighted also that sometimes after harvesting surplus do occur at the time of harvest depending on the market demand, processing and preservation advice is given by the extension agents but not in the last two years on practical skill training aspect. The advice normally given is normally on agronomy practices rather than on crop produce loss and though useful however, lack of other areas like the post-harvest technology which could possibly due to lack of extension, frequency of operation, or skills operated in the schemes thus reflecting on farmers low interaction with the extension agents. Formal educational level is suggested to have an influence on knowledge of post-harvest handlers and these observations affirm the findings by Kereth et al. (2013) that indicated both formal educational and post-harvest knowledge gaps which in turn affect agricultural activities within the entire food chain, especially post-harvest handling.

Table 4

\begin{tabular}{l|rrrrrr} 
Horticultural Farm and Training Type \\
\hline & \multicolumn{7}{c}{ Training Type } \\
Horticultural Farm/Organisation & Harvesting & Handling & Packaging & Storage & Agronomy Total \\
\hline Dasilami & 0 & 0 & 2 & 0 & 137 & 139 \\
Marakessa Vegetable Garden & 0 & 0 & 0 & 0 & 83 & 83 \\
Lamin Women Garden & 0 & 0 & 0 & 0 & 60 & 60 \\
Banjulunding Vegetable Garden & 5 & 1 & 0 & 2 & 33 & 41 \\
Young Farmer's Club & 9 & 0 & 0 & 8 & 21 & 38 \\
Sukuta Women's Garden & 14 & 0 & 1 & 18 & 4 & 37 \\
\hline Total & 28 & 1 & 3 & 28 & 338 & 398 \\
\hline & (Source: Field survey 2018) & & &
\end{tabular}

\section{Horticultural Farm and Number of training}

Data derived from the field about number of training conducted at the horticultural farms across the two districts in the area indicated in terms of identifying the influencing access is shown in table 5 below. In table 5 below revealed the schemes and number of training conducted, there was not frequent training. The results show the highest number of training conducted was the Taiwanese time (17: 4\%) who experienced some form of training in all the schemes, 14: 3.5\% had yearly training while the rest (367: 92\%) had never attended any training while. At individual scheme, majority had not attended any training for instance: Dasilami (136:98\%) out of the 139 respondents, Marakissa (82:99\%) out of 83 respondents, Lamin (55: 92\%), and all others. Some schemes only had training during Taiwanese time (Sukuta, Banjuluding and 
Marakessa). This has also indicated that there was less extension operation in most of the schemes as training was not frequent especially post-harvest handling practices.

During the FGD, it has also been pointed out there was no training conducted at their individual schemes and it was confirmed that those few individuals who had training was not at the scheme rather at private sponsored at some time stationed at another part of the country and even that was not frequently conducted.

Table 5

Horticultural Farm and Number of Training

\begin{tabular}{l|rrrrrrrrrrr}
\hline & \multicolumn{1}{|c}{ Daily } & \multicolumn{1}{c}{ Weekly } & Monthly & \multicolumn{3}{c}{ Yearly } & I don't Know \\
Horticultural Farms & F & $\%$ & F & $\%$ & F & $\%$ & F & $\%$ & F & $\%$ \\
\hline Dasilami & 0 & 0 & 0 & 0 & 0 & 0 & 3 & 2 & 136 & 98 \\
Marakessa & 1 & 1 & 0 & 0 & 0 & 0 & 0 & 0 & 82 & 99 \\
Lamin & 0 & 0 & 0 & 0 & 0 & 0 & 5 & 8 & 55 & 60 \\
Banjulunding & 12 & 29 & 0 & 0 & 0 & 0 & 0 & 0 & 29 & 41 \\
Busumballa & 0 & 0 & 0 & 0 & 0 & 0 & 6 & 16 & 32 & 38 \\
Sukuta & 4 & 11 & 0 & 0 & 0 & 0 & 0 & 0 & 33 & 37 \\
\hline \multicolumn{7}{c}{ Source: Field survey 2018) }
\end{tabular}

\section{Horticultural Farm and Post-Harvest Training Technology}

Data derived from the field about post-harvest training at different horticultural farms in the area indicated that there has been less or no post-harvest training done as shown in table 6 below. From the results in the table 6 below, very few farmers had any form of post-harvest technology in all the schemes (36 out 398 respondents about 9\%) while 362 (91\%) did not have any post-harvest technology training. At the individual schemes, it was only Bajulunding garden $(11,29 \%)$ out of the 38 respondents in the scheme) that had the highest of post-harvest technology training than any other which even below 50\%. This could also be due to either extension mode of operation is inadequate or did not have post-harvest technology skills and further their operation is not much frequent at the schemes. This therefore implies that with less knowledge and skills of the farmers in post-harvest practices, there will be high losses of produces.

During the FGD, it has also been pointed out there was no or few post-harvest trainings conducted at their individual schemes and it was confirmed that those few individuals who had training was not at the scheme rather at private sponsored at some time stationed at another part of the country and even that was not frequently conducted.

Table 6

Post-Harvest Training at Horticultural Farms

\begin{tabular}{l|rrrr}
\hline & \multicolumn{5}{|c}{ Post-Harvest Training Technology } \\
Horticultural Farm/Organisation & Yes & $\%$ & No \% & Total \\
\hline Dasilami & 4 & 3 & 13597 & 139 \\
Marakessa Vegetable Garden & 2 & 4 & 8196 & 83 \\
Lamin Women Garden & 7 & 12 & 5388 & 60 \\
Banjulunding Vegetable Garden & 11 & 27 & 3073 & 41 \\
Young Farmer's Club & 6 & 16 & 3284 & 38 \\
Sukuta Women's Garden & 6 & 16 & 3184 & 37 \\
\hline Total & 36 & $(9.05 \%)$ & $362(91.95 \%)$ & 398 \\
\hline
\end{tabular}

(Source: Field survey 2018) 


\section{Horticultural Farm and Advice Area}

Data derived from the field about advice given to the different horticultural farms are mostly concentrated on agronomic practices as shown in table 7 below. The extension advises to the horticultural schemes also play a very significant influence on the farmers change to any new innovations. The results in table 7 above show that various advice given at the schemes. Out of the different advises given, $230((57.79 \%)$ out 398. respondents said there was no advice given by extension agents. The area where advice was given, the highest was crop husbandry (91: $22.86 \%$ ). On the side of post-harvest technology only (21: 5.28\%) were given advice showing that post-harvest technology and extension operation in this area was not given much attention. During FGD, it has also been pointed out that there is little advice from the agriculture but mainly on production and diversification rather than on post-harvest handling techniques. However, the main constraint is available, reliable and access to market, lack of storage facilities, and water shortage were highlighted.

Table 7

Horticultural Farm/Organisation and Advice Area

\begin{tabular}{l|rrrrrrrr}
\hline $\begin{array}{l}\text { Horticultural } \\
\text { schemes }\end{array}$ & $\begin{array}{r}\text { Crop } \\
\text { Husbandry }\end{array}$ & $\begin{array}{r}\text { Crop } \\
\text { Diver. }\end{array}$ & $\begin{array}{c}\text { Animal } \\
\text { Husb. Mketing }\end{array}$ & $\begin{array}{r}\text { Irrigation } \\
\text { dev. PHT }\end{array}$ & \multicolumn{2}{c}{$\begin{array}{l}\text { Others } \\
\text { (none) Total }\end{array}$} \\
\hline Dasilami & 33 & 4 & 14 & 6 & 0 & 2 & 80 & 139 \\
Marakessa & 19 & 0 & 3 & 0 & 0 & 2 & 59 & 83 \\
Lamin & 0 & 0 & 8 & 0 & 0 & 17 & 35 & 60 \\
Banjulunding & 8 & 0 & 1 & 1 & 0 & 0 & 31 & 41 \\
Busumbala & 13 & 6 & 3 & 0 & 0 & 0 & 16 & 38 \\
Sukuta & 18 & 2 & 7 & 0 & 1 & 0 & 9 & 37 \\
\hline Total & 91 & 12 & 36 & 7 & 1 & 21 & 230 & 398 \\
\hline
\end{tabular}

(Source: Field survey 2018)

\section{CONCLUSION AND RECOMMENDATIONS}

Another finding is that, extension operation at the horticultural schemes are available to majority of the schemes and their activities in the area while but not at regular base that is monthly visit is the most times of visit to most of the schemes and this was supported during FGD discussion. Those who had been having regular visits were due to easy proximity, access and good road conditions to the schemes by the extension agents who were expected to guide and show farmers what they to do. The farming methods used at the various schemes however were mostly improved method a frequency and of all the trainings done, agronomy practices were the highest while post-harvest training are very rare. It was also found out that the schemes and number of training conducted, there was not much frequent training and very few farmers had any form of post-harvest technology in all the schemes. Furthermore, Agricultural extensions services were available to majority of the farmers, however, there were not regular frequent visits and training with the horticultural schemes. That has affected slow improvement of especially on post-harvest technology.

The study came out with the following recommendations: continued research and development programmes which can be undertaken by Government, NGOs and research institutions to provide a strong basis for knowledge dissemination and documentation are recommended; Research findings must however be communicated to the farmers using appropriate means regular farmer field schools, demonstration; Information on horticultural production and post- 
harvest handling be readily available at the Department of Agriculture food technology and on the internet through various agencies, the challenge of accessibility, mode of training, and dissemination to smallholder horticultural farmers that will addressed through the use of frequent extension services, farmer or producer groups, farmer field days and forums for information exchange; and government and other players in the agricultural sector plan initiatives to educate both extension agents and smallholder farmers on the benefits of proper post-harvest handling practices as an effective means to curb/limit the negative effects of fresh produce post-harvest losses.

\section{References}

Adomi, E. E., Ogbomo, M. O., \& Inoni, O. (2003). Gender factor in crop farmers' access to agricultural information in rural areas of Delta State, Nigeria. Library Review, 52, 388393

Anderson, J. R., \& Feder, G. (2004). Agricultural extension: Good intentions and hard realities. World Bank Research Observer, 19, 41-60.

ANR, (2009). Agriculture and Natural Resources (ANR) Policy (2009-2015): The Republic of The Gambia: http://qanet.gm/statehouse/agriculture/achievements.html

Benor, D., Harrison, J.Q., \& Baxter, M. (1984). Agricultural Extension: The training and visits system. Washington, DC, USA: The World Bank.

Birner, R. Davis, K., Pender, J., Nkonya, E., Anandajayasekeram, P., Ekboir, J., \& Bollen, A.F. (2006). Technological innovations in sensors for assessment of postharvest mechanical handling systems. International Journal of Postharvest Technology and Innovation, 1, $15-33$.

Braun, A., Jiggins, J., Roling, N., van den Berg, H. \& Snijders, P. (2005). A global survey and review of farmer field school experiences. Report prepared for the International Food Policy Research Institute. Wageningen: Endelea.

Dávila, O. G. (2010). Food security and poverty in Mexico: the impact of higher global food prices. Food Security 2, 383-393.

Department of Agriculture. (2013). The Agricultural and Natural Resource Policy, Republic of The Gambia

Gêmo, H. C., Eicher K., \& Teclemariam, S., (2005). Mozambique's experience in building a national extension system, East Lansing, MI: Michigan State University Press.

Government of The Gambia (GOTG), (2010). The Gambia Country Paper and Action Programme 2001--2010 Third United Nations Conference on The Least Developed Countries, Brussels, 14-20 May 2001, A/CONF.191/CP/35

Government of The Gambia Report (GOTG), (2008). Initiative on Soaring Food Prices (ISFP), Republic of The Gambia; Final Report Situation Assessment and Country Action Plan

Kombo D.K \& Tromp, D.L. (2006). Proposal and thesis writing' An introduction, Nairobi: Paulines Publications Africa

Lewin P.A. (2011). Three Essays on Food Security, Food Assistance, and Migration (PhD thesis), Oregon State University

Martins, R.B., Hogg, T., \& Otero, J.G. (2012). Food handlers' knowledge on food hygiene: The case of a catering company in Portugal. Food Control, 23: 184-190.

National Agricultura Survey (NAS, 2013). Pre-Harvest Crop Assessment 2012, Department of Planning, Ministry of Agriculture, Republic of The Gambia

Nyangweso, P.M., Odhiambo, M.O., Odunga, P., Korir, M.K., Kipsat, M.J., \& Serem, A.K. (2007). Household food security in Vihiga district, Kenya: determinants of dietary and diversity. African Crop Science conference proceedings, 8, 1383-1389.

Orodho A.J (2004). Techniques of Writing Research Proposal and Reports in Education from LIT 0605 at Nova Southeastern University 
Owens, T., Hoddinott, J., \& Kinsey, B. (2003). The impact of agricultural extension on farm production in resettlement areas of Zimbabwe. Economic Development and Cultural Change, 51, 337-357.

Rivera W. M. \& Qamar, M. K. (2003). Agricultural Extension, Rural Development and the Food Security Challenge, Extension, Education and Communication Service Research, Extension and Training Division Sustainable Development Department, Food and Agriculture Organization of The United Nations, Rome, pp5

Rivera, W. M. (2001). Whither Agricultural Extension Worldwide? Reforms and Prospects. In S. D. Z. Wolf, ed. Knowledge generation and technical change: Institutional innovation in agriculture. Berkeley: University of California.

World Bank. (2003). A Multi-Country Agricultural Productivity Programme (MAPP) for Africa. (Draft). Washington, DC

Yamane, T. (1973). Statistics An Introductory Analysis ( $3^{\text {rd }}$ edn.), Harper and Row, New York Yudelman, M. (1984). Foreword. Training and visit extension. Benor, D. \& Baxter, M. (eds.). Washington, D.C.: A World Bank Publication. 